УДК $615.846 ; 615.844$

\title{
ИСПОЛЬЗОВАНИЕ МАГНИТОТЕРМИИ ПРИ ЛЕЧЕНИИ ЗЛОКАЧЕСТВЕННЫХ НОВООБРАЗОВАНИЙ. II
}

ЛОШИцкИй П. П., НИкОЛОВ Н. А.

\author{
Национальный технический университет Украинь \\ «Киевский политехнический институт», \\ Украина, Киев, 03056, пр-т Победы 37
}

\begin{abstract}
Аннотация. Рассмотрены неоднородные тепловые и магнитные поля, связанные с изменением геометрии антенны-аппликатора и их влияние на конвективные потоки крови, переносящей лекарственные препараты
\end{abstract}

Ключевые слова: магнитная антенна; диффузия; конвекция; турбулентность; магнитотермия

\section{1. ВВЕДЕНИЕ. ПОСТАНОВКА ЗАДАЧИ}

В [1] рассмотрен круг вопросов, связанных с конвективной устойчивостью движения жидкости, обусловленной наличием тепловых и магнитных полей, которые поясняют особенности магнитотермии при лечении злокачественных новообразований [2]. При этом вклад самих магнитогидродинамических эффектов крайне мал [3]. Однако, если приложенные тепловые и магнитные поля будут неоднородны и эта неоднородность направлена на увеличение нестабильности потока крови, то эффективность магнитотермии повышается.

Повышение эффективности связано с тем, что лекарственные препараты поступают в раковые клетки не равномерно, а случайным образом, за счет увеличения эффективной перфузии патологических тканей. Такой эффект наиболее полно реализуется при турбулентном потоке, однако в кровеносном русле естественная турбулентность возможна только в крупных артериях. Поэтому создание искусственных условий для конвективной неустойчиво- сти содействует повышению эффективности примененного лечебного метода.

Целью настоящей работы является повышение эффективности магнитотермии при помощи введения неоднородностей магнитного и теплового полей, и анализ режимов течений.

\section{2. БИОЛОГИЧЕСКИЕ ПРЕДПОСЫЛКИ}

Одним из примеров синхронизации колебаний в живых клетках, помещенных в один раствор, служат пульсации размеров ядер в клетках асцитной карциомы Эрлиха. Размер ядер этих клеток изменяется в среднем в 1,5 раза с периодом около часа. Период репродукции клеток порядка суток. Кроме размеров ядер, колеблются размеры самих клеток, а также проницаемость плазматических мембран. При этом проницаемость мембран клеток злокачественных образований достаточно велика, а все процессы, в том числе и митоз, в таких клетках протекают интенсивно.

Учитывая что большой процент клеток в любой опухоли не делится, клетки находятся в «законсервированном» состоянии. Возможно 